\title{
Participation of Surakarta Children Forum in Development Planning Deliberation: Between Bureaucratic Formalism and Human Governance
}

\author{
S. Yuliani, R. H. Haryanti \\ Public Administration Science \\ Faculty of Social and Political Sciences \\ Universitas Sebelas Maret Surakarta, INDONESIA \\ julie_fisip@yahoo.com
}

\author{
R. Humsona \\ Department of Sociology \\ Faculty of Social and Political Sciences \\ Universitas Sebelas Maret Surakarta, INDONESIA
}

\begin{abstract}
Surakarta Children Forum is an association of young people deliberately set up as a medium for children's participation in the development planning process. Children's participation in development is one important indicator of public administration paradigm that respects the rights of children. Using data from Surakarta Children Forum and Badan Perencanaan Daerah Kota Surakarta (Regional Planning Agency of Surakarta City), this qualitative research addressed two questions: firstly, could the Surakarta Children Forum serve as a means of giving a voice to children in the development planning; secondly, how far does bureaucratic formalism affect the participation of Children Forum in Development Planning Deliberation. The result of research found that Children Forum are not involved at all stages of development planning and their voices have not been fully accomodated in regional budget. Children's participation in development planning is still low due to the children do not have the awareness of children's rights and lack of ability to communicate and express their aspirations. Barriers to participation of children also come from bureaucrats who think children are not able to make decisions. To municipal government, establishment of Children's Forum understood merely as a formality to meet the demands of the rules, rather than to fulfill a substantial function as a medium for the aspirations of the child in development planning. The research findings prove that children's participation in development planning in the city of Surakarta have not been able to manifest the fulfillment of children's rights (Human Governance).
\end{abstract}

Keywords: Participation, Children Forum, Bureaucratic Formalism, Human Governance

\section{INTRODUCTION}

Children's participation in development planning has now become both international and national agendas. At global level, the United Nations' Convention on the Rights of the Child in Article 12 states that the State guarantees the right of the child to express his views on all matters concerning him in accordance with the age and maturity of the child. At national and local levels, children's participation in development planning is mandated by the Child Protection Act [1] and is one indicator of a childfriendly city. One of children's participation policies is the establishment of media to listen and to convey aspirations, opinions and expectations of children as a form of children's participation in the development process, called Children Forum [2]. Recognizing the importance of children's participation, the Government of Surakarta establishes Surakarta Children Forum as an element of society involved in Musyawarah Perencanaan Pembangunan (Development Planning Deliberation). Musyawarah Perencanaan Pembangunan, abbreviated as Musrenbang, is a multi-stakeholder forum within the framework of regional development plan.

The problem is that although the right of children to participate in decision making concerning their need is increasingly recognized, no enough medium is available for the children's participation and if it is so, it is not able to ensure the real participation. Often children's participation is just intended to satisfy the procedure or formality. Arnstein (in Hart 1992) [3] distinguishes forms of child participation into several levels: 1) Manipulation, 2) Decoration, 3)Tokenism, 4)Assigned but informed, 5) Consulted and informed, 6) Adult initiated, shared decisions with children, 7) Child initiated and directed, and 8) Child initiated, shared decision with adults Manipulation is the lowest level of participation. Here the child does not understand the issue to be solved so he does not know what reason underlying an action. Here children should only consult, but they were not asked to give feedback. Decoration, here children participate only as participants or is just used to indicate that the program has involved children. Tokenism, here the children seem to have been given opportunity and media to convey aspirations, but not opportunity to formulate their own opinion. If no explanation is given to the children, how they were selected and the perspective of the child which they represent, are usually sufficient indications that the project is not truly participatory. The third typology of participation - manipulation, decoration and tokenism- is not the actual participation or pseudo participation, so Arnstein categorizes them into non-participation one.

Children's participation is influenced by many factors. One key factor is socio-economic background. Many studies found that different community layers have different levels of participation. A review conducted by Kirby and Bryson on 27 studies found that adult and women groups are the most widely participating ones. Meanwhile, young people of marginalized groups have the lowest participation rates. Marginalized groups with low participation rates are young people with physical disabilities or minority ethnic groups [4]. People with socio-economic status tend to participate more. Young people generally participate less than older people. [5] mentioned the existence of intrinsic and extrinsic barriers to children's participation. Intrinsic barriers are related to 
characteristics of bureaucracy and professionalism, including an organization's rules and regulations, and its structure having maze-like property and tensions between the goals and objectives of the public bureaucracy. Extrinsic barriers are social contexts, economics, politics, and culture in which the organization works and these things can greatly inhibit the level and effectiveness of participation. The structural position of people in the community may affect who participates and who does not. complicated structural bureaucratic and internal political factors also become obstacles to children's participation [4] . In addition, the attitude and the behavior of adults who lack confidence in the ability of the child make the program "adult-focused". As a result, a lot of the agenda and program implementation processes are controlled by adults and the elderly. Matthews argues that nonparticipation culture is still very strong; there is an "invisible network" or some sort of control by adults who make children's thinking and decisions excluded. PercySmith mentioned that one obstacle to children's participation is socio-economic force that limits children's participation in development planning, including a difficult relationship with local government and the failure to unite the diverse voices, [4]. Therefore, active participation, according to Shier 6], will only occur when adults are willing to share power by delegating or transferring some of their power to the children.

Consider the fact that children's participation in development planning is an important indicator of childfriendly city, this research aimed to know whether or not the Surakarta Children Forum is capable of being a medium to voice the children's interests in development planning and the extent to which bureaucratic formalism affects the quality of participation of the Children Forum in Development Planning Deliberation.

\section{METHODS}

This research was a qualitative descriptive research. Informants were selected purposively consisting of the Surakarta Regional Development Planning Board and the Agency for Community Empowerment, Women and Child Protection; stakeholders in children's participation in development, namely KOMPIP and SOMPIS; as well as children who are members of the Children Forum in Surakarta. In addition, this study also utilized secondary data source deriving from documents, archives, government regulations and data obtained from newspapers, magazines, and Internet-related research themes. Data collection was carried out using observation, in-depth interviews and focus group discussions (FGDs) methods. Data analysis was carried out using an interactive model including three components: data reduction, data presentation, drawing conclusions. [7]

\section{RESULT AND DISCUSSION}

\section{A. Participation of Surakarta Children Forum in Development Planning Deliberation: A Tokenism Model}

Children's participation is the involvement of children in decision-making processes relating to their lives, which is implemented based on the awareness, understanding and maturity of the child's thinking. Surakarta Children Forum is an organization of young people set up by the Government of Surakarta as a medium to convey aspirations and participation of children, particularly in urban development planning meetings is a forum between actors in order to construct annual planning and budgeting of national and regional development. Musrenbang was implemented under Law 25 of 2004 on National Development Planning System.

The implementation of development planning in many Indonesian cities has been organized through a technocratic (top-down) approach and involved only territorial-based community participation, while participatory-based development planning involving all stakeholders, including the Children Forum, has not run optimally yet.

Participatory development planning in Surakarta has been started since 2001, known as Musyawarah Kelurahan Membangun (muskelbang) or village level development deliberation, sub-districts level development deliberation (Musyawarah Perencanaan Membangun), and city level development deliberation (Musyawarah Kota Membangun). Deliberation on three levels involves multi-stakeholder community followed by two bases: territorial basis or representation of RT (neighborhoods association), Rukun Warga (resident's associations) and community leaders and sectoral basis (representation of the community, such as community rickshaws, street vendors, buskers and so on).

Since 2013, the Children Forum has been one of the communities included in the sectoral planning forums. Through involving the Children Forum in the development planning, the children are expected to convey ideas and issues related to their needs. The development of Children Forum in Surakarta began around 2008 with the establishment of children forum at (municipal) city level called Surakarta Children Forum (Forum Anak Surakarta/FAS). Until 2012 it has been established 27 village levels of Children Forum, one (1) children forum at district level, and one (1) children forum at municipal level.

Evaluation of Children Forum [8] concluded that the Children Forum in Surakarta cannot function optimally as a medium to channel the aspirations of children, particularly in Development Planning Meeting (Musrenbang). In addition, not all villages have a Children Forum, in 51 urban villages in Surakarta city there are only 27 Children Forums. At the District and city (Municipal) levels, there is one Children Forum in each of them: Pasar Kliwon Children forum and Surakarta Children Forum.

In 2015, Yuliani, Haryanti and Humsona found that almost all of 51 urban villages in Surakarta have developed Children Forum [9]. The research concluded that children's participation in planning forums is still limited to the formation of the medium only, not to the substance of the children involvement in determining the pro-child development programs. There are several factors contributing to lower participation in the Children Forum Musrenbang. From the Children Forum, it can be seen no awareness of children's rights, in addition to the capacity and capability of the Children Forum to get involved in giving a voice and decision-making that are still weak. And the fundamental obstacle is the institutional bureaucracy; it was found that the bureaucratic work 
culture promoting strong formalism is still attached, so there is no strong desire to actually engage children actively in development planning.

\section{B. Human Governance versus Bureaucratic Formalism}

Policies to accommodate the child voice in the planning process are a form of manifestation of public sector governance models that respect human rights and democratic values or Human Governance. The main indicator of human rights-based governance includes participation as a means and a goal; empowerment as a strategy; and programs focused on the realization of the rights of vulnerable groups [10] [11].

Children's participation in development policy has a strong legal support, namely Article 24 of Law No. 23 of 2002 on Child Protection, mandating the State and the Government to ensure the children using their right of expression freedom according to their age and intelligence level and State Minister for Women Empowerment and Child Protection Regulation (Peraturan Menteri Negara Pemberdayaan Perempuan dan Perlindungan Anak or Permeneg PP \& PA) No. 03 of 2011 on Children Participation in Development. In Permeneg $P P \& P A$ No.03 of 2011, Child Participation is defined as involvement of children in decision-making processes about anything related to him and carried on awareness, understanding and willingness together so that children can enjoy the result or benefit from the decision. Meanwhile child is a person who has not turned into 18 (eighteen) years.

Surakarta Children Forum has been established since 2008. However, the Children Forum has not been able to perform its function as a vehicle by which children participate in development planning. "Children Forum" is involved in planning forums in 2014 with the enactment of the Mayor of No. 20 of 2013 on Implementation and Technical Guidelines for Development Planning Meeting Surakarta Year 2014. In this rule "Children Forum" is mentioned as a part of a community that is included in the sectoral planning forums [3].

Although there has been a forum for children's participation supported by a strong legal basis, but in practice, the implementation of children's participation is limited to providing the children with the opportunities of arguing about their desires and wishes, while the final decision remains in the hands of the local elite. A child is allowed to voice their aspirations, but there is no guarantee that child aspirations will be accommodated in the development policies decided by the local government elite.

There are several factors leading to weak participation of the Children Forum in development planning. From the Children Forum there are lower awareness of children rights, lack of understanding of the function and mechanism of children's participation in planning forums and limited ability to articulate and convey ideas and proposals. In essence, children's participation has not been supported by the bargaining power, the ability to conduct lobbying, negotiation, and compromise. Therefore, organizations or NGOs companions, not the Children Forums, are actually dominant in pushing the interests of children to be accommodated in the planning forum.
The obstacle of the implementing agency is poor commitment to really involving the children in planning and accommodating the ideas and proposals presented by the child in the development budget. This happens because on the one hand the executive agencies still do not believe in the children's ability of thinking maturely. Children are still considered as not mature enough to be able to express opinions or ideas related to their interests in the development. On the other hand, the most fundamental factor is the strong culture of bureaucratic formalism among public officials.

Formalism is a tendency to favor the look or procedure rather than the substantial things [12]. Bureaucracy making the procedure an end is not the means referred to as "bureaucratic proceduralism". Defined bureaucratic proceduralisme as [13]:

Bureaucratic procedural's is defined as organizational practices occurring through the interaction of formal rules and procedures with informal administrative activities. This focus on procedural's directs empirical attention to the processes that affect the cost of claiming, not on the categorical standards for eligibility themselves. It recognizes that eligibility rules are not self-executing, but depend on the formal and informal steps, interactions, and judgments that constitute the business of claims making at the street-level.

The behavior of bureaucrats who are more concerned with acting merely to comply with the rules and procedures formalism and procedurals, occurs because the bureaucracy very strongly holds on the rules, regulations, and the formal procedure.... when a bureaucracy sticks to formalized rules, regulations and procedures for a long time, the eventual result is that the rules become more important than achievement of organizational goals. Adherence to rules becomes a value and the bureaucrat no longer sees rules merely as means to achieve ends. It leads to formalism, ritualism, technical and red tape [14].

Bureaucratic formalism can be observed from the tendency of government officials (Surakarta Regional Development Planning Board or BAPPEDA and The Agen for Community Empowerment, Women and Child Protection) to include the Children Forum in Musrenbang more as a form of obedience to the procedure rather than a commitment to fulfilling the rights of children in development. What are important are formal and procedural provisions of the law mandated to involve children in the development plan that has been executed. The real issue that the development planning documents do not accommodate the voices of children is not important.

KOMPIP (Consortium for Public Institutions Monitoring and Empowerment) and NGOs providing guidance on community planning forums said that behavior of bureaucracy has not changed much, they tend to emphasize on rules and procedures. BAPPEDA kota Surakarta as important actors in participatory development planning defines children's participation merely as a physical presence in Musrenbang. For them, participation was manifested by providing a channel for the aspirations of children through the establishment of Children Forum. 
The similar case is found in Central Java, where children's participation in Musrenbang takes place more at the village level, but there is a decline in the level of further deliberation: "In fact, children's participation in Musrenbang just a formality. Children voices heard at Musrenbang village, but in Musrenbang higher level, most of the proposals that contain the aspirations of children rejected for the sake of sectoral agencies. ". [16]

Similar cases were also reported in Jayapura. Participants of Diskusi Kelompok Terbatas (Focus Group Discussion) including government and NGO workers reported that suggestions and ideas from the public were not accommodated in the town plan, or were not included in the program budget. A government official in Jayapura stated: "Musrenbang is just a formality. Musrenbang is held because we have to do it. But we cannot say that it represents the voice of the community if people's needs are not taken into consideration in the planning and implementation of policies resulting from Musrenbang." [16].

Model of participatory development planning has not become a bureaucratic mindset. Real practice in the planning and development is a top-down approach. The participatory approach becomes a wrap or legitimacy for the implementation of development planning, because the real power in decision-making remains in the hands of the regional executive.

\section{CONCLUSION}

The primary mission of the establishment of Children Forum is to provide a medium for children's participation in development planning and budgeting in order to accommodate the needs and aspirations of children. But this mission is difficult to realize because there are internal and external obstacles. Internal factors are lower awareness of children rights and the Children Forum's capacity and capability of getting involved in giving a voice and decision-making. The fundamental barriers are external constraints in the form of a bureaucratic culture that emphasizes formalism, so there is no political will to actually engage children actively in development planning.

Using the typology of participation from Arnstein [3], children's participation Forum in Musrenbang can be referred to as manipulation, decoration and tokenism type of participation. It is called manipulation because the children involved in the development planning deliberation do not fully understand what and how their roles are. Children are only asked to voice their aspirations without knowing whether or not their aspiration will be realized in the development plan. Decoration, participation of Children Forum in Musrenbang so far serves only as formalism used to show that development planning has involved children. Tokenisme, Children Forum is formed simply to show that the government has provided a forum to channel the children's aspiration, although the substantive functions to be actively involved in planning forums is not optimal.

In the case of children's participation in Musrenbang in Surakarta, we found that there are many children proposals not absorbed in the development planning. The government is more concerned with their own program plans. This happens because the government does not believe in the children's ability of proposing strategic ideas. Consequently, the development program nonetheless puts the interests of adults or is "adult focused" (Percy-Smith in Cavet and Sloper, 2004).[7]

This research concluded that participation of Children Forum in Musrenbang in Surakarta is not a form of active participation but pseudo-participation. Children Forum has not been actively involved in Musrenbang, particularly in influencing and participating to make a decision. Participation was limited to the Children Forum to gain legitimacy for the policies formulated by the government.

\section{REFERENCES}

[1] Law No.23 of. 2002 about Child Protection

[2] Republic of Indonesia State Minister for Women Empowerment and Child Protection's Regulation No.04 of 2011 about Manual of Children Participation in Development

[3] Surakarta Mayor Regulation No.18-A of 2012 about Technical Guides of Development Planning Discussion for Surakarta City in 2013.

[4] Hart, Roger.A., 1992. Children's Participation: From Tokenism to Citizenship. UNICEF International Child Development Centre.

[5] Lansdown, Gerison . 2001. Promoting Children's Participation in Democratic Decision Making. United Nation Children's Fund, Innocenti research Center. Florence, Italy.

[6] Thomas, Nigel. 2007. Towards a Theory of Children's Participation. International Journal of Children's Rights 15

[7] Cavet, J and Sloper, P. 2004. Children's participation and young people in decisions about UK service development. Social Policy Research Unit, University of York, Heslington, York, UK

[8] Ife, Jim and Frank Tesoriero. 2008. Alternatif Pengembangan Masyarakat di Era Globalisasi: Community Development. Yogyakarta: Pustaka Pelajar

[9] Report of Monitoring and Evaluation on Children Forum of 2012. Bappeda Kota Surakarta ((Regional Planning Agency of Surakarta City)

[10] Nasahsh, Hyam. Toward Human Governance in Public Administration Through Quality of Education. Paper presented in 2010 United Nations Public Service Day - Awards Ceremony and Forum " The Role of Public Service in Achieving the Millenium Development Goals : Challenges and Practices". 21-23 Juni 2010. Barcelona. Spanyol. 2010.

[11] Baccini, M. Human Governance : For a New Culture of Public Administration on the Humanization of Public Administration. Global Forum on Reinventing Government. Seoul. 2005

[12] Formalism. Citing internet sources http://indonesialawonline.com/lib \%20Formalism.aspx.

[13] Brodkin, Evelyn Z. and Majmundar, Malay . 2008. Organizations and Exclusion: An Inquiry Into Bureaucratic Proceduralism . National Poverty Center Working Paper Series. Citing internet source http://www.npc.umich.edu/publications/working_papers/ ?publication_id $=155 \&$

[14] Ahmed, Helal Uddin. 2014. Bureaucratic Dysfunction : a theoritical review. Citing internet source http://www.thefinancialexpress-bd.com/2014/11/03/64212

[15] Unicef Indonesia. 2012. Making Decentralisation Work for Children in Indonesia. Citing internet source http://www.unicef.org/indonesia/A2E_Issue Brief Decentralisation_REV.pdf 